\title{
Harmoni, Stabilitas Politik dan Kritik Sosial
}

\author{
Susetiawan
}

\section{Pendahuluan}

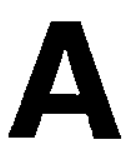

da ungkapan menarik untuk memulai tulisan ini. Ungkapan berikut dikutip dari pendapat Taufik Abdullah: kata ketika dinaikkan tingkatannya menjadi sebuah konsep, maka kesatuan maknanya menjadi problematik. Kamus pun tak berfungsi sebagai penunjuk makna sebab tidak lebih hanya sekedar pemberi indikasi arti kata. Penentuan makna seringkali bersifat hegemonik yang bertolak dari kepentingan kekuasaan.' ungkapan tersebut menunjukkan betapa sulitnya memahami sebuah kata dalam tutur kata atau bahasa dalam kehidupan sosial. Kata tidak hanya sekedar mengandung arti melainkan juga lebih utama bagaimana publik memaknai sebuah kata dalam kehidupan. Arti kata seringkali bukan merupakan makna sesungguhnya dalam realitas sosial.

Misalnya kata kritik, arti harfiah yang dapat diperoleh dari kamus bahasa Indonesia adalah kecaman atau tanggapan yang sering disertai oleh argumentasi baik maupun buruk tentang suatu karya, pendapat, situasi maupun tindakan seseorang atau kelompok. ${ }^{2}$ Ketika kritik dilakukan dengan arti harfiah tanpa mengingat budaya yang sedang berlangsung seperti di Indonesia sekarang ini, pelakunya bisa mendapat imbalan yang tidak menguntungkan sebab mengkritik bisa dianggap memusuhi. Penerima kritik bukan lagi memahami sebagian koreksi atau kontrol dari orang lain terhadap keterbatasan pemikiran atau tindakan, baik secara individual maupun kelompok, tetapi menganggapnya sebagai kebencian.

Bagaimanapun konsep kritik yang sedang berlangsung sekarang di negeri ini tidak dapat dipisahkan dengan budaya dan era pembangunan. Oleh karena kritik adalah kritik membangun yang pemaknaannya lebih banyak didominasi oleh kepentingan kekuasaan. Makna utamanya adalah jelas yakni untuk meniadakan kritik itu sendiri dalam artian hartiah. Apa yang dikehendaki dari kritik membangun tidak lebih dari sekedar saran, petunjuk-petunjuk dan bukan sebuah kecaman atau kontrol yang dapat membawa malu atau menyakitkan

'Ungkapan ini digunakan oleh Taufik Abdullah untuk memulai tulisannya tentang Strategi Kebudayaan untuk Pemberdayaan Masyarakat: Sebuah Sketsa Penjelajahan Metodologis dalam Media inovasi, Jurnal UMY, No. 2 Tahun VII 1996, hal. 7.

${ }^{2}$ Meskipun ada beberapa tambahan dari penulis sendiri, inti kutipan diatas diambil dari Kamus Besar Bahasa Indonesia, diterbitkan oleh Departemen Pendidikan dan Kebudayaan. 
bagi penerima kritik. Jika hal ini dilakukan oleh seseorang maka perbuatan itu akan dianggap tidak cocok dengan budaya yang ada dan mengganggu harmoni kehidupan sekelompok orang yang memiliki kekuasaan. Dengan demikian dua kata, yakni antara kritik dan membangun, tidak dapat dipisahkan dalam kesatuan konsep. Penempatan kata pun tidak boleh keliru atau terbalik. Artinya orang harus menggunakan kata kritik sebagai diterangkan sedang membangun sebagai menerangkan dalam tatanan bahasa Indonesia yang benar. Pada umumnya orang akan menerima konsep kritik membangun dari pada menggunakan dua kata tersebut dalam susunan kata terbalik yakni membangun kritik. Susunan kata terakhir ini terdengar aneh yang kemungkinan akan membawa fungsi penting dalam kehidupan masyarakat yang sedang mengalami kebekuan.

Oleh karena itu eufimisme yang sedang berlangsung dalam masyarakat tidak dapat dihindarkan. Kecenderungan menghaluskan kata sering kali dilakukan oleh setiap orang untuk mengungkapkan kekurangan orang lain agar tidak mengganggu perasaan dan bukan membuka kelemahan pemikiran untuk merubah tindakan. ${ }^{3}$ Lahirnya substansi kritik sosial menjadi kurang jelas, namun hal ini merupakan warna budaya yang dapat diterima oleh semua pihak. Eufimisme bahasa sebagai alat untuk mengungkapkan kritik sosial, menurut hemat penulis, adalah produk budaya, yakni berupa produk pemikiran yang cenderung dikontruksikan oleh kepentingan yang erat kaitannya dengan kekuasaan.

Dalam pada itu, pengungkapan kritik baik dalam bahasa lisan maupun tulisan sering dibumbui oleh penghamburan katakata yang tidak perlu sehingga menunjukkan kalmat berputar-putar yang akibatnya sulit dipahami isi sesungguhnya dari peng- ungkapan kritik yang dimaksudkan. Maksud utama eufimisme ini adalah jelas yakni tidak membuka secara transparan dari kekurangan orang lain atau lebih tepat lagi apabila ditujukan pada elit penguasa.

Jika demikian halnya, ada beberapa pertanyaan yang cukup menarik untuk dibahas. Pertama, pilihan asumsi macam apa yang pada umumnya berlangsung di dalam masyarakat sehingga kritik tidak dapat transparan? kedua, apa hubungannya dengan harmoni sebagai ideologi? Ketiga, apa implikasi tindakan politik dalam kehidupan sosial? Keempat, dapatkah cara ini dipertahankan untuk menghadapi jaman baru pada abad 21? Kelima, adakah alternatif untuk memahami kritik sosial yang tidak menghilangkan prinsip harmoni? Beberapa pertanyaan ini akan menjadi tekanan dalam pembahasan dibagian berikut.

\section{Pilihan Asumsi Dasar Pemikiran}

Banyak variasi pemikiran dalam memahami perkembangan masyarakat, sedikitnya ada tiga hal penting yang akan dikemukakan. Alasan utama pemaparan variasi pemikiran tentang perkembangan

3pada konggres Indonesia 1978, Mucthar Lubis memberika sinyalemen bahwa Eufimisme bahasa akan membawa erosi akan arti kata. Gunawan Muhammad mempertanyakan hal ini bahwa eufimisme hanya sekedar peralihan kata dari satu kata ke kata yang lain yang tidak membawa erosi makna. Alfian berpendapat lain meskipun terjadi eufimisme tetapi hal itu dapat dimengerti oleh masyarakat sebab telah terjadi konsensus sosial. Bahasan tentang hal ini terdapat pada Ignas Kleden dalam buku Sikap Ilmiah dan Kritik Kebudayaan, Bab. $\mathrm{X}$. 
masyarakat pada bagian ini adalah untuk memahami realitas tindakan dalam hubungannya dengan aspek sosial, ekonomi, politik dan budaya dalam suatu negara. Bentuk pemikiran pertama, orang mempercayai bahwa masyarakat itu berkembang karena hubungan-hubungan konflik yang melibatkan berbagai macam kepentingan. Hubungan konflik dilukiskan dalam bentuk hubungan kelas yakni antara kelas penguasa dan kelas yang dikuasai. Hubungan konflik antara satu suku bangsa dengan suku bangsa lain tidak kurang dari penentuan suku bangsa mana yang menjadi taklukan dan yang lain menjadi suku bangsa yang memiliki dominasi. Demikian seterusnya masyarakat akan terus berkembang karena perbedaan-perbedaan kepentingan.

Konflik kepentingan yang bersifat internal maupun eksternal selalu berakibat pada perubahan dan perkembangan masyarakat itu sendiri. pada mulanya asumsi dasar pemikiran ini menunjuk pandangan yang sangat ekstrim yakni penganutnya percaya bahwa perjuangan kelas untuk menegakkan kepentingannya akan berakhir dengan tumbangnya kelas lain yang semula memegang dominasi. Meskipun pada akhirnya perjuangan kelas tidak harus diartikan dengan peperangan yang menghancurkan secara fisik dari kelas lain, setidaknya pergantian posisi kekuasaan dapat membawa perbedaan dalam penataan perkembangan masyarakat sesuai dengan kepentingan yang sedang berkuasa. Kesimpulan yang dapat diambil dari pemikiran ini adalah setiap masyarakat akan berkembang melalui posisi perbedaan-perbedaan atau konflik antar kelas. Misalnya masyarakat industri, masyarakat ini terbentuk akibat dari berbagai macam konflik kepentingan yang menempatkan para kapitalis sebagai pemegang dominasi hingga kini.

Bentuk pemikiran kedua, pemikiran ini tidak mengingkari bahwa masyarakat ber- kembang karena perbedaan-perbedaan atau konflik kepentingan kelas. Istilah yang digunakan untuk kelas penguasa dengan kata dominasi sedang yang dikuasai dengan kata subordinasi. Meskipun dalam perjalanan sejarah perkembangan masyàrakat selalu ditandai dengan peperangan dan saling menumbangkan antara satu dengan yang lain, dalam perkembangan masyarakat modern, sebagaimana ditunjukkan oleh masyarakat barat saat ini, tumbangnya kelas penguasa oleh kelas yang dikuasai tidak terjadi. Meskipun demikian posisi hubungan konflik akan berjalan terus dan akhirnya setiap kelas memiliki posisi tawar-menawar untuk mencapai kepentingan yang saling menguntungkan di antara mereka.

Pada tahap perkembangan ini institusiinstitusi sosial, politik dan ekonomi secara budaya mengalami perubahan besar dengan menjamin keberlangsungan institusi tawar-menawar yang dijamin oleh nilai yang ditegakkan dalam hukum formal. Dengan demikian semua kepentingan publik dapat terjamin. Artinya kesepakatan akan tercapai ketika semua pihak telah terjamin kepentingannya. Pelanggaran terhadapnya akan diberikan sanksi sesuai dengan tatanan hukum. Berkembangnya hukum modern yang menjamin kepentingan publik tidak dapat lepas dari institusi politik yang menempatkan demokrasi sebagai media untuk menjamin hak bagi setiap individu. Keadaan demikian akan berlangsung jika hubungan sosial tidak lagi herarkial tetapi egaliter.Keseluruhan ini merupakan perubahan budaya yang menempatkan pemikiran bahwa pada dasarnya masyarakat itu tersusun dalam hubungan konflik disatu pihak, sedang di pihak lain ada hubungan harmonis yang ditunjukkan dalam bentuk kerjasama. Pada tingkat ini istilah pelestarian budaya tidak pernah ada. Penonjolan nilai budaya terletak bagaimana nilai tradi- 
sional yang menjamin kepentingan publik dipertahankan dan dimapankan dalam sistem hukum formal yang menjamin kepastian dalam kehidupan sosial.

Bentuk pemikiran ketiga, perkembangan masyarakat dilihat dari perubahan sistem kemasyarakatan dari semula bentuk tradisional ke bentuk modern. Sistem kemasyarakatan dilihat dari terintegrasinya sub-sub sistem di dalam mana masingmasing memiliki peran dan saling fungsional terhadap subsistem lain. Sungguhpun dalam pemikiran ini mengakui ada perbedaan tetapi perbedaan tidak dianggap sebagai hubungan konflik. Perbedaan yang ada dalam kehidupan sosial ditihat sebagai bentuk pembagian kerja (division of labour). Konflik dianggap sebagai bentuk penyimpangan yang senantiasa dianggap sakit dan sering dianggap memberi kontribusi terciptanya disintegrasi dalam sistem sosial.

Dalam bentuk sistem kemasyarakatan tradisional digambarkan bahwa hubungan diantara subsistem yang ada berlangsung secara longgar, aturan-aturan yang ada lebih bersifat informal dan hubungan sosial lebih bersifat mekanistik. Dengan berkembangnya tuntutan manusia, sistem kemasyarakatan tradisional berubah. Perubahan yang ada menunjukkan kompleksitas peranan dan fungsi. Aturan yang ada berlangsung formal dan hubungan sosial yang terjadi lebih organik. Dalam pikiran ini agak tidak begitu jelas menerangkan prosesnya bagaimana masyarakat berubah dari bentuk semula tradisional ke modern. Penjelasan utamanya lebih ditekankan pada karakter bentuk tradisional dan modern yang berlainan sama sekali. Pendek kata, pemikiran ini lebih menekankan proses integrasi sebagai unsur yang mendorong perkembangan dan mengabaikan konflik karena dianggap tidak mendukung kemajuan (progress) masyarakat itu sendiri. ${ }^{4}$ Menurut hemat penulis, suku bangsa Jawa lebih memilih bentuk pemikiran terakhir. Pada umumnya pemikiran ini banyak mewarnai pandangan orang-orang Indonesia secara budaya yang dikontruksikan oleh para. elit yang memegang dominasi. Adalah jelas kepentingannya yakni untuk menciptakan kepatuhan dan loyalitas terhadap para pemegang kekuasaan. Kekuasaan itu dapat berlangsung dimana-mana baik mulai dari organisasi terkecil dalam masyarakat yang disebut keluarga sampai dengan negara. Mulai dari pendidikan keluarga sampai dengan pendidikan formal. Misalnya anakanak sekolah telah dikenalkan sebuah ungkapan yang mendambakan akan keharmonisan kehidupan sosial yang terhindar dari konflik. Yakni ungkapan bersatu kita teguh bercerai kita jatuh, ungkapan ini dapat pula dimaknai bentuk integrasi yang membuat bangsa ini sangat kuat dan konflik akan membuat keruntuhan. Ungkapan tersebut tidak jauh berbeda dengan ungkapan dalam bahasa Jawa yakni crah agawe bubrah (konflik atau berbeda pendapat akan menuju kehancuran). ${ }^{5}$ Meskipun ungkapan

${ }^{4}$ Uraian tiga pemikiran ini berasal dari pemikir besar seperti Karl Mark, Max Weber dan Durkheim. Pikiran ini selain disarikan dari tulisan Anthony Giddens Kapitalisme dan Teori Sosial Modem juga telah menjadi pembahasan dalam desertasi saya Culture Values Organization and Work Performent of industrial Workers in Indonesia (unpublished).

${ }^{5}$ Konflik pada dasarnya adalah pertentangan atau antagonis yang sifatnya bermacam-macam mulai batin, pikiran sampai dengan perselisihan fisik. Yang bersifat pikiran, konflik dapat berujud perbedaan pendapat. Perbedaan ini sering diungkapkan dengan cara bersifat kritis terhadap suasana. Dengan demikian kritik merupakan penampilan (manifes) manusia, misalnya perbedaan pemikiran yang menjadi salah satu bentuk konflik, konflik bisa terjadi secara laten. 
ini tidak banyak disebut-sebut dalam pendidikan keluarga tetapi nilai yang terkandung di dalamnya melekat dalam pendidikan sehari-hari. Setidaknya orang tua akan memarahi anaknya apabila anak banyak berbeda pendapat dengan yang lain atau bertengkar mulut, apalagi dengan orang tua. Situasi semacam itu akan dianggap tidak menciptakan hubungan sosial yang menuju kepada keharmonisan.

Sadar atau tidak bahwa pemikiran ini telah mewarnai tindakan keseharian yang berhubungan dengan kompleksitas kehidupan secara sosial dan politik. Akibat selanjutnya diam adalah lebih baik dari pada kritis. Kalau sikap kritis ingin ditunjukkan setidaknya harus mengatur tutur bahasa yang diperhalus. Tindakan semacam ini biasanya banyak diterima karena masih memenuhi kriteria sopan-santun dalam pergaulan hidup bermasyarakat. Dalam realitas keseharian,baik dulu maupun sekarang, pikiran kritis selalu hadir dalam kehidupan masyarakat Indonesia mulai dari petani sampai dengan para pekerja yang hidup di kota. Pada tingkat kehidupan petani, Sartono Kartodiharjo telah memaparkan peasent revolt yang terjadi di Banten. ${ }^{6}$ Sikap kritis, karena sering dikontruksikan sebagai bentuk yang akan menghasilkan disintegrasi, sering tidak menguntungkan bagi pribadi yang bersikap kritis di mata pemegang dominasi. Pilihan pemikiran ini akan dicoba untuk memahami bagaimana berlangsungnya periode pembangunan dan akibat yang ditimbulkannya.

\section{Implikasi Tindakan dalam Era Pembangunan}

Pembangunan sebagai usaha untuk merubah masyarakat kenyataannya melahirkan fenomena yang sekaligus berlawanan. Disatu pihak pembangunan menjadi kebanggaan bangsa karena menghasilkan pertumbuhan ekonomi, sedang di pihak lain pertumbuhan ekonomi tinggi membentuk tingkat kesenjangan ekonomi, sosial dan politik yang semakin lebar. Pemerataan belum menjadi kenyataan dan masih merupakan angan-angan, apakah hal ini dapat atau tidak dicapai sebagai cita-cita yang diharapkan, tergantung bangșa Indonesia sendiri untuk mewujudkannya. Masalah kesenjangan tidak hanya terjadi di Indonesia melainkan juga di negara-negara berkembang pada umumnya. Pertumbuhan ekonomi, prosentase terbesar dinikmati oleh sebagian kecil penduduk, sedang sebagian besar penduduk menikmati sebagian kecil dari hasil pertumbuhan. Berbagai realitas ketimpangan ini sudah sejak tahun 1980 an dibicarakan oleh banyak pakar. ${ }^{7}$ Namun ada pertanyaan penting yang perlu dikemukakan disini sehubungan dengan perkembangan Indonesia; mengapa kesenjangan itu terjadi? Apakah perkembangan ekonomi membutuhkan sistem baru/ Penjelasan tentang hal ini dapat dilakukan dengan berbagai versi penjelasan. Salah satu penjelasan akan dikemukakan dalam bagian ini yang khususnya berhubungan dengan pilihan asumsi pemikiran sebagaimana dikemukakan di atas.

Prinsip utama pelaksanaan pembangunan di indonesia menekankan pada terciptanya stabilitas politik guna mendukung pertumbuhan ekonomi. Setidaknya ada beberapa alasan tentang hal ini. Per-

'Tulisan tentang radikalisme petani-petani Jawa banyak dikemukakan dalam tulisan Sartono Kartodirdja, Ratu Adil.

${ }^{7}$ Meskipun orang telah banyak berbicara tentang ketimpangan salah seorang yang pernah menjabat sebagai representatif Bank Dunia, Mahbub Ulhaq, membahasnya tentang hal ini di negara berkembang, Tirai Kemiskinan. 
tama, ada alasan pemikiran yang didukung oleh pengalaman historis yakni kegagalan pemikiran rezim orde lama yang tidak mampu mengangkat perkembangan ekonomi bangsa Indonesia. Kedua, situasi sosial dan politik yang penuh dengan konflik dan perbedaan pada jaman orde lama dianggap tidak mendukung perkembangan ekonomi negara. Ketiga, alasan legitimasi budaya bahwa konflik dan perbedaan diharamkan oieh nilai budaya bangsa karena tidak mendukung kehidupan yang harmonis.

Secara teoritik orang dapat mengerti terhadap bentuk pemikiran ini. Namun orang dapat tidak percaya terhadap argumen pemikiran tersebut tatkala realitas menunjukkan fenomena yang berlainan. Meskipun pertumbuhan ekonomi saat ini jauh lebih baik daripada jaman orde lama, bentuk kekerasan, kejahatan yang menunjukkan situasi konflik, frekuwensinya meningkat akhir-akhir ini. Perbedaan perkembangan ekonomi antara jaman orde lama dan baru hanya terletak pada kebijaksanaan luar negeri yang memanfaatkan hutang dan investasi asing di Indonesia. Kebijaksanaan orde lama yang tidak memanfaatkan sebanyak-banyaknya utang luar negeri untuk pembangunan bangsa mengakibatkan keterlambatan perkembangan ekonomi bangsa Indonesia pada waktu itu. Menurut hemat penulis keterlambatan perkembangan Indonesia pada waktu itu bukan semata terletak pada situasi yang penuh dengan konflik dan perbedaan di antara golongan-golongan yang ada, tetapi ideologi rezim orde lama tentang pembangunan bangsa.

Hal ini yang perlu dikemukakan pada bagian ini adalah bagaimana prinsip stabilitas dipahami dan siapa yang memegang dominasi serta bagaimana pemahaman terhadapnya dikontruksikan kembali pada masyarakat. Ketika stabilitas politik digelar sebagai syarat utama tegaknya pembangunan maka pengertian stabilitas politik lebih banyak didominasi oleh para, elit penguasa. Stabilitas politik tidak lain dimaknai dengan situasi tanpa konflik yang ditunjukkan oleh fenomena musyawarahmufakat. Oleh karena itu tidak mengherankan jika demokrasi lebih banyak dimaknai oleh kepentingan kekuasaan dengan istilah demokrasi Pancasila yang intinya menolak demokrasi liberal. Istilah demokrasi dalam terminologi ini adalah penghalusan bahasa yang maknanya lebih memperkecil kehidupan konflik atau perbedaan diantara kelompok masyarakat. Banyak istilah yang menggunakan kata Pancasila seperti Hubungan Industrial Pancasila, Pers Pancasila dan seerusnya, namun kata Pancasila lebih banyak digunakan sebagai legitimasi untuk menepis segala perbedaan dan hadirnya kritik sosial terhadap keadaan yang berkembang dalam rangka pembangunan. Pancasila tidak lagi dijunjung untuk menegakkan kebenaran empiris sebagaimana dalam cita-cita tetapi sebagai kebenaran politis dalam ruang lingkup kepentingan kekuasaan.

Pada aras ini keadaan yang sedang berlangsung menjadi tidak jelas, apakah telah berlangsung stabilitas politik dengan menjamin perbedaan-perbedaan secara seimbang atau cenderung berlangsung politik stabilitas. Kata stabilitas atau bentuk kehidupan harmonis menjadi kunci utama dalam menangani segala persoalan yang berhubungan dengan perbedaan atau konflik. Ketika perbedaan-perbedaan berlangsung dalam kehidupan masyarakat, yang dianggap tidak menguntungkan bagi kepentingan elit penguasa, ada kecenderungan untuk dieliminasikan dengan cara mulai dari menakut-nakuti sampai dengan menekan. Misalnya dalam konflik perburuhan, penanganan terhadap hal ini sering menghasilkan kerugian dipihak buruh. Salah satu 
contoh yang masih dapat diingat oleh banyak orang adalah kasus Marsinah. ${ }^{8}$ Hasil yang ditimbulkan oleh cara memahami harmoni seperti tersebut di atas, menurut hemat penulis, tidak menghadirkan harmoni atau stabilitas itu sendiri sebab kontlik dan perbedaan semakin lama terus berkembang dan tidak kunjung akan surut. Pada aras ini kata stabilitas sering kali hanya menjadi alat politik bagi sekelompok orang atau individu yang merasa memiliki kekuasaan.

Bentuk penekanan untuk membuat stabilitas diciptakan pula secara simbolik melalui bahasa. Misalnya dalam kehidupan pers, pers bebas dan bertanggung jawab adalah simbolisasi dari peringatan terhadap pers jika para wartawan menyajikan berita dengan memberikan kritik sosial dengan keras atau menggunakan bahasa yang cukup jelas yang dapat dipahami maksudnya oleh masyarakat. Hal ini akan dianggap menciptakan kegelisahan dan mempengaruhi masyarakat yang berakibat pada turunnya kewibawaan pemerintah. Meskipun kontrol terhadap kehidupan masyarakat dari elit penguasa sangat besar, kritik sosial tidak akan berhenti. Wujud bahasa yang digunakan dalam kritik menggunakan pilihan bahasa secara, halus misalnya șindiran, perumpamaan dan semacamnya. Bentuk kritik sosial yang cenderung dengan penghalusan bahasa tercipta oleh keadaan struktur masyarakat yang tidak egaliter. Dalam struktur masyarakat yang sangat hierarkhis segala macam bentuk kritik tidak mungkin akan berkembang secara transparan sebab kritik merupakan bentuk perbedaan yang tidak dikehendaki oleh penguasa. Kehidupan semacam ini menunjukkan fenomena amad 16 di dalam mana kehidupan masyarakat dikuasai seluruhnya oleh bentuk monarkhi absolut.

Pembangunan yang menggunakan dasar pemikiran yang meletakkan prinsip stabilitas politik untuk mewujudkan terciptanya proses integrasi, dalam kenyataannya memiliki kelemahan sebab stabilitas diterjemahkan sebagaimana situasi tanpa konflik. Akibat yang ditimbulkan adalah digunakannya kata stabilitas bukan untuk kepentingan publik tetapi alat bagi kelompok yang berkuasa. Sadar atau tidak hal ini akan berpengaruh terhadap berbagai tindakan strategis mana kalakonflik dan perbedaan dengan kelompok penguasa semakin meluas dikalangan masyarakat Indonesia yang terdiri dari berbagai macam suku bangsa dan agama. Tindakan strategis bagi penguasa sangat bervariasi untuk mengkontruksikan kehidupan harmoni dalam situasi sosial yang berkembang akhir-akhir ini. Menurut hemat penulis hal ini perlu mendapat perhatian secara seksama.

\section{Institusi-Institusi Sosial, Ekonomi dan Politik}

Akibat pemikiran menekankan harmoni, dalam bahasa pembangunan disebut stabilitas, dan ketakutan akan disintegrasi, institusi-institusi sosial, ${ }^{9}$ ekonomi dan po-

${ }^{8}$ Kasus Marsinah hanya saiah satu contoh kasus perburuhan yang sangat ekstrim, masih banyak kasus lain yang tidak mungkin akan diungkap satu persatu tentang perburuhan ini. Meskipun telah ada undang-undang perburuhan yang baru nasib buruh masih belum banyak mendapatkan perlindungan yang layak dalam hak-hak asasi manusia.

${ }^{9}$ Pengertian institusi disini lebih banyak menekankan hubungan-hubungan sosial yang terpola. Koentjaraningrat menterjemahkan institusi dengan istilah pranata. Intinya pranata ini terletak pada suatu kelakuan yang terpola, Kebudayaan Mentalitas dan Pembangunan, hal. 14 
litik berlangsung dengan beberapa cara yang sesungguhnya tidak mendukung integrasi. Pertama, penghargaan terhadap hakhak kemanusiaan menjadi kurang terjamin. Kedua, ada kecenderungan untuk menciptakan homogenitas pemikiran guna mendukung berlangsungnya kekuasaan. Ketiga, nepotisme menjadi institusi dominan dalam pengerahan tenaga dalam organisasi baik sosial, ekonomi dan politik. Keempat membuat tuduhan terhadap perbuatan tangantangan setan (invisible hand) atas segala kejadian yang tidak mendukung prinsip harmoni. Keempat perkembangan institusi ini berlangsung di segala bidang kehidupan.

Dalam bidang sosial yang berhubungan dengan hukum, pembelaan terhadap hakhak kemanusiaan masih jauh dari jaminan kepastian hukum, meskipun bangsa ini telah 50 tahun merdeka. Pada umumnya institusi hukum tergantung pada hubungan antara pihak penguasa dan yang dikuasai. Dalam hubungan ini aturan hukum lebih berjalan secara individual untuk menjamin kepentingan individu dan bukan berorientasi pada kepentingan publik. Salah satu contoh yang sedang berlangsung saat ini adalah terbunuhnya seorang wartawan Harian Bernas, Fuad Syafrudin, akibat penganiayaan yang hingga kini pembunuhnya belum diketemukan. Dalam pemberitaan media massa banyak diungkap keterkaitan pejabat tinggi nomor satu tingkat daerah Kabupaten Bantul. Meskipun Lembaga Pembela Hukum (LPH) melakukan pembelaan terhadap orang yang disangka pihak kepolisian sebagai pembunuh Udin, yang menurut keyakinan pembela bukan pembunuhnya sebab tidak cukup bukti, hingga kini lembaga tersebut belum banyak membuat keberhasilan. ${ }^{10} \mathrm{Hal}$ lain erat relevansinya dengan tidak adanya kepastian hukum adalah merebaknya kasus korupsi, kolusi, penggelapan uang Bank dan sejenisnya. Institusi semacam ini, kelihatan- nya, menjadi pilihan rasional bagi sebagian besar anggota masyarakat. Perjuangan ke arah institusi hukum modern kelihatannya masih panjang dan penuh dengan tantangan untuk menegakkan nilai keadilan dan kebenaran yang berorientasi pada kepentingan masyarakat luas.

Kecenderungan menciptakan homogenitas pemikiran semakin tampak ketika institusi yang berlangsung di Dewan Perwakilan Rakyat di amati secara seksama. Produk Undang-Undang yang dihasilkan, jika dibandingkan jumlahnya antara apa yang dibuat oleh badan legislatif dan eksekutif, oleh Dewan Perwakilan Rakyat sangat sedikit, sedang Dewan lebih banyak berfungsi untuk menyetujui Undang-Undang yang dibuat oleh pemerintah. Akhir-akhir ini dalam Dewan Perwakilan rakyat, yang terdiri dari wakil partai politik, tidak diperkenankan ada oposisi. Institusi semacam ini jarang terjadi pada sebuahbangsa yang memiliki negara modern dan mengaku negara demokrasi.

Dalam organisasi ekonomi, organisasi pemerintahan dan keanggotaan calon legislatif diwarnai oleh semangat nepotisme dan bukan atas dasar kualifikasi kemampuan seseorang yang pantas menduduki tempat terhormat guna mengembangkan organisasi dan mampu mengartikulasikan kepentingan masyarakat. Makna kepentingan repotisme ini tidak lain adalah untuk menegakkan prinsip budaya harmoni de-

10Sejak terbunuhnya Syafrudin hingga saat ini harian Bernas tidak lekang memberitakan kasusnya setiap hari. Berdasarkan pemberitaan menurut hemat penulis baik LBH maupun LPH belum banyak mengalami kemajuan di dalam melakukan pembinaan hingga detik ini tulisan ditulis. Perjuangan LBH dan kawan-kawan memang tidak ringan sebab berhadapan dengan kekuasaan yang represif. 
ngan kemungkinan konflik yang dapat merusak proses integrasi.

Apabila tahun 1995-1996 disimak; setidaknya ada tiga belas peristiwa besar menyangkut kerusuhan. Berbagai masalah kerusuhan menurut kubu pemerintah diakibatkan oleh SARA, menyatakan karena kesenjangan sosial-ekonomi. Dua analisis yang berlainan antara para pakar sosial di satu pihak dan pemerintah dipihak lain menjadi pertanyaan besar. Apa yang sesungguhnya sedang berlangsung terhadap situasi sosial-politik saat ini? Akhir-akhir ini ada tuduhan bahwa ada intektual di belakang kerusuhan. Selain dari pada itu, kerusuhan akhir-akhir ini disinyalir oleh kubu pemerintah ada dalang atau ada rekayasa di belakangnya. Namun hingga detik ini semuanya belum pernah terbuktikan secara konkrit aktor mana dan siapa dalang atau perekayasa di belakang kerusuhan. ${ }^{11}$ Setiap kerusuhan selalu diberi label adanya pihak ketiga, namun siapa pihak ketiga itu? Karena adanya pihak ketiga tidak pernah jelas, penulis menggolongkan sebagai tangan-tangan setan.

Istilah pihak ketiga, dalang, perekayasa dan SARA adalah boom untuk masyarakat. Siapa pun dapat menggunakan kata ini dalam kehidupan masyarakat sehingga persoalan yang ada tetap tidak pernah terbuka, apa dan siapa yang menjadi sebab. Situasi ini semakin membuat kecurigaan antata satu dengan yang lain yang tidak pernah jelas duduk persoalannya. Siapapun yang menggunakan strategi untuk mencapai kehendaknya bukan bentuk manajemen konflik (managed conflict) tetapi tepat disebut sebagai managed devide et impera. Istilah terakhir ini digunakan oleh pemerintah Belanda terhadap pribumi Indonesia. Sebelumnya tak pernah ada konflik. antara suku bangsa Cina dan Islam pribumi pada waktu itu. Kedua suku bangsa ini menjalin kerja sama dalam dunia perda- gangan. penempatan strata satu terhadap golongan orang Eropa, strata kedua untuk golongan orang Cina dan Timur Asing, sedang strata ketiga adalah pribumi yang dibedakan haknya oleh pemerintah Belanda, menurut interprestasi penulis Belanda hanya ingin memindahkan konflik pribumi Islam terhadap pemerintah ke orang-orang Cina yang kemudian mewarisi fenomena sosial masa kini.

Cita-cita untuk menciptakan integrasi dengan menjunjung tinggi filsafat harmoni ternyata mengandung banyak kelemahan. Harmoni menjadi idola bagi kelompok atau individu yang senantiasa dapat diguna-kan sebagai strategi untuk menekan bentuk konflik atau kritik sosial yang dianggap mengganggu kepentingan kelompok yang memiliki kekuasaan. Pada aras ini ketakutan akan kehilangan status quo sekelompok orang, dialihkan menjadi ketakutannya terhadap proses disintegrasi bangsa untuk mendapat legitimasi publik. Kelemahan integrasi nasional terletak pada penempatan pikiran tentang harmoni yang dipahami bahwa masyarakat selalu hidup rukun dan perbedaan selalu dianggap negatif. ${ }^{12} \mathrm{Pada}$ akhirnya persoalan bangsa Indonesia saat ini seperti kerusuhan tidak dapat dipahami

"Menpangab Faisal Tanjung, terang-terangan mengatakan bahwa pihaknya telah mengetahui aktor kerusuhan Tasikmalaya (26 Desember 1996) dan di Situbondo pada buIan Oktober 1996, majalah Forum Keadilan No. 21 tahun V, 27 Januari 1997, hal. 12 s/d 15.

${ }^{12}$ Resensi buku "Cultural identity \& Global Process" dari tulisan Jonathan Friedman oleh Bambang Hudayana, Salah satu tesis Friedman: Jika integrasi nasional lemah, maka kebudyaan lokal relatif lestari sehingga tetap terpelihara pertalian kebudayaan masa silam dan masa kini, Jurnal kebangsaan Indonesia, Vol. 1 No. 1, 1997, hal. 106. 
sepotong-sepotong, tetapi perlu dipahami secara holistik dan sistemik.

Karena ide harmoni dalam masyarakat hierarkhis dipahami sebagai bentuk masyarakat tanpa konflik, akibatnya ide harmoni hanya digunakan untuk mengesahkan sekelompok orang yang berkuasa, untuk meniadakan bentuk konflik atau kritik terhadap status quo. Akibat dari tindakan ini demokratisasi hanya mendapat tempat dalam mulut dan bukan pada tindakan. Demikian pula kalau demokrasi harus ada maka bentuk ini harus sesuai dengan konsep penguasa. Kritik sosial yang bersifat transparan terhambat. Dengan demikian sistem hukum yang menjamin kepastian dalam

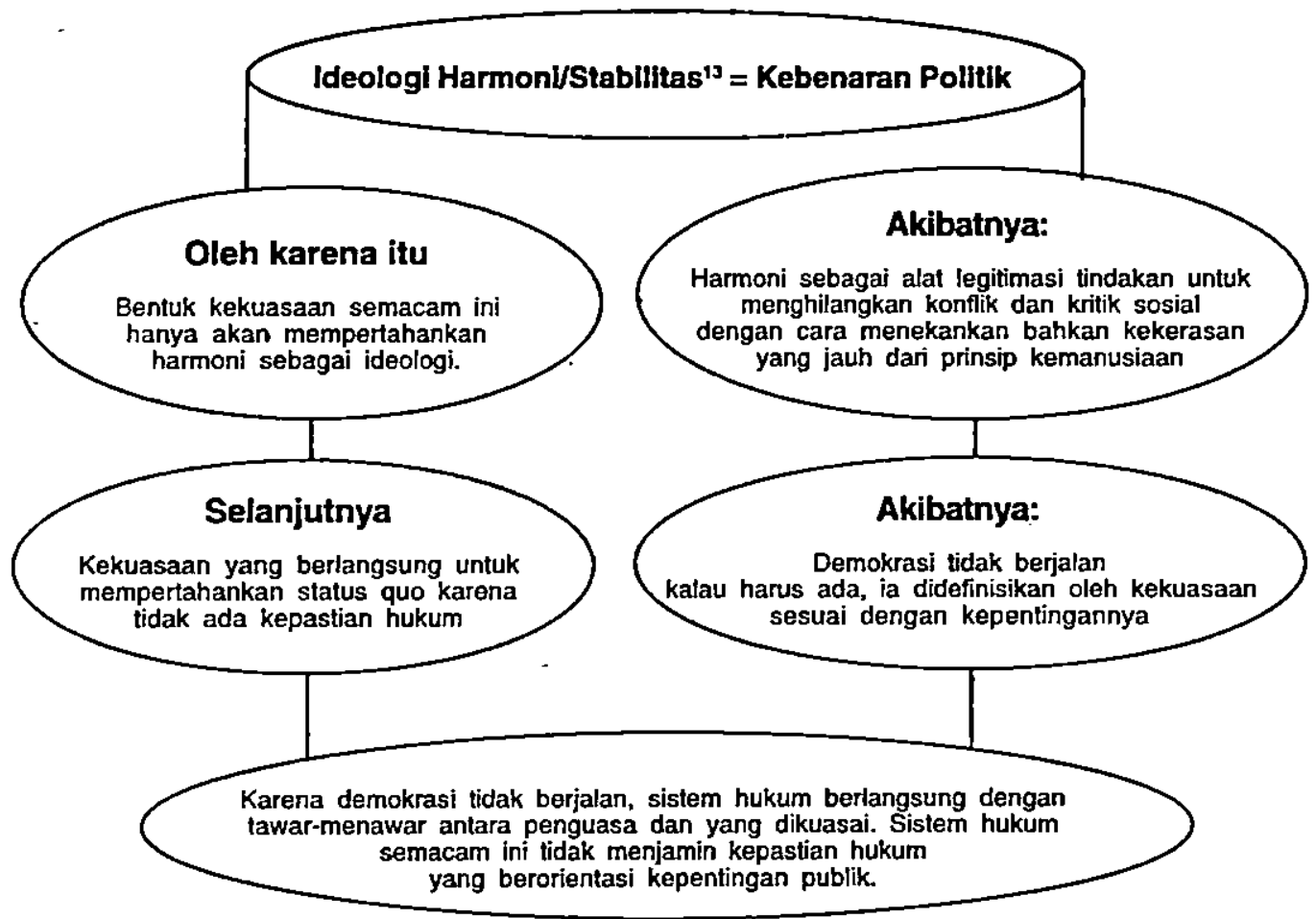

${ }^{13}$ deologi menurut hemat penulis merupakan sistem kepercayaan yang membenarkan suatu tatanan untuk meraih cita-cita, oleh karena itu aplikasinya membutuhkan strategi, prosedur, instruksi dan seterusnya. Ideologi biasanya dikaitkan dengan literature Marxian. Pada umumnya karakter ideologi sangat ditentukan oleh perubahan ekonomi dan biasanya ideologi diputar balikkan oleh kepentingan klas, lihat Nicholas. A, Dictionary of Sociology. 
kehidupan sosial juga tidak pernah ada. Hukum pada umumnya masih berupa katakata dalam undang-undang. Sedang institusi yang berjalan adalah diatur antara penguasa dan yang dikuasai. Institusi hukum semacam ini fungsional terhadap kemapanan kelompok yang berkuasa yang senantiasa sensitip terhadap kritik apapun yang terjadi. Kritik sosial dan konflik akan semakin besar manakala penekanan dan ancaman terhadap masyarakat semakin besar. Pada saat ini pula masyarakat akan kehilangan kepercayaan terhadap penguasa.

Statement di atas merupakan interpretasi penulis atas dasar pemikiran yang berlangsung di Indonesia. pernyataan di atas merupakan lingkaran penafsiran di dalam mana setiap kejadian terkait secara sistematik.

Sistem ini berlangsung dalam seluruh masyarakat yang dapat disaksikan hampir dalam setiap organisasi baik sosial, ekonomi dan politik. Jika demikian halnya, persoalan yang akan dihadapi pada abad 21 menjadi lebih sulit karena hal ini akan terkait dengan sistim nilai universal yang menjadi kesepakatan umum mengenai hakhak kemanusiaan. Kontrol dan kritik tidak hanya berjalan dalam lingkup nasiona! melainkan juga internasional. Dapatkah sistem ini dipertahankan untuk menghadapi era mendatang? Tentu, hal ini sulit dipahami kalau sistim yang beriangsung pada abad 16 digunakan dalam era abad 21.

\section{Konflik dan Kritik Sosial untuk Kehidupan Harmoni}

Dalam setiap masyarakat, konflik dan kerjasama selalu berjalan bersama-sama. Salah satu tidak dapat menghapuskan yang lain. Artinya, jika terjadi kerjasama bukan berarti konflik tidak pernah akan terjadi, demikian sebaliknya.
Perkembangan masyarakat sampai dengan masyarakat industri ditandai dengan Institusi konflik maupun kerjasama. Oleh karena itu sebuah pemikiran yang berusaha untuk menghapuskan konflik untuk mencapai masyarakat yang absolut harmonis adalah mustahil. Harmoni akan berlangsung tergantung bagaimana masyarakat atau sistem kekuasaan yang ada memahaminya. Memahami harmoni sekaligus memahami kontlik demikian sebaliknya memikirkan konflik untuk mewujudkan cita-cita harmoni.

Pada umumnya negara-negara Asia Tenggara juga menggunakan prinsip yang sama yaitu harmonis. Negara seperti Singapura, Thailand, Philipina, Malaysia pada prinsipnya tidak jauh dari Indonesia di dalam mana harmoni menjadi dasar filsafat kehidupan. Meskipun mereka memiliki prinsip yang sama tetapi ada pemahaman yang berbeda dengan Indonesia. Misalnya di negara-negara mereka pemogokan diatur di dalam undang-undang. Pada umumnya memperbolehkan pemogokan asal bukan pada sektor publik. ${ }^{14}$

Diperbolehkannya buruh mogok berarti harmoni dipahami sebagai suatu situasi yang mempertimbangkan konflik meskipun setiap negara ASEAN ada beberapa variasi. Akhir-akhir ini di Indonesia, dengan undang-undang baru, buruh diperkenankan mogok. Undang-undang baru ini lahir bukan karena kerelaan tetapi karena kritik internasional tentang kesesuaiannya undangundang di Indonesia dengan Labour Code dari ILO. Meskipun pemogokan diizinkan

${ }^{14}$ Basu Sharma, memberikan penjelasan tentang paham harmoni yang pada umumnya digunakan di negara-negara ASEAN untuk mendasari hubungan industrial. Hal ini dikemukakan dalam buku Aspects of Industrial Relation in ASEAN, hal. 49-75 
tetapi sebelum pemogokan/aksi unjuk rasa dilakukan, pihak buruh harus melaporkan lebih dahulu tentang aktifitas yang akan dilakukan. Tindakan ini adalah sebuah bukti bahwa paham harmoni ternyata dipahami berbeda-beda diantara negara satu dengan yang lain. Harmoni di Indonesia tetap dipahami dalam konteks semula meskipun pemogokan buruh diizinkan.

Keluarnya undang-undang perburuhan baru di negeri-Ginseng berakibat pada pemogokan buruh secara besar-besaran di negeri ini, krisis hubungan industrial yang terjadi di Korea akhir-akhir ini menelan kerugian ekonomi sangat besar. Pada tanggal 21 Januari 1997 presiden Kim Young Sam mengakui bahwa UU perburuhan yang baru sangat bermasalah. la akan membicarakan kembali di parlemen dan mempertimbangkan suara oposisi. ${ }^{15}$

Sungguhpun Korea Selatan pada umumnya tidak jauh berbeda dengan negara-negara Asia Timur, yakni prinsip harmoni menjadi bagian kehidupan mereka, toleransi terhadap konflik yang dilakukan oleh penguasa menunjukkan bahwa paham harmoni sangat berbeda seperti dilakukan di Indonesia.

Adakah alternatif pemikiran lain tanpa menghilangkan prinsip harmoni atau stabilitas? Prinsip stabilitas bagaimanapun tidak harus hilang tetapi paham bagaimana kita mengerti tentang stabilitas itulah yang mestinya harus berubah. Jika stabilitas hendak dipahami kembali, tentu pikiran baru tentangnya tidak harus mengabaikan atau membenci konflik dan kritik sosial. Kritik sosial tidak dipahami sebagai instrumen untuk terciptanya disintegrasi tetapi sebuah koreksi terhadap kekuasaan untuk menciptakan proses integrasi. Paham pikiran ini akan membawa implikasi tindakan yang berbeda dari paham terdahulu.

Berpikir tentang harmoni atau stabilitas, pada saat yang sama orang juga berpikir tentang konflik dan esensinya. Pada aras ini managed conflict adalah penting sebab intinya adalah mengelola pihak-pihak yang berkepentingan menuju keseimbangan dengan mengatur melalui sistem hukum yang menjamin kepastian hukum. Jika harmoni atau stabilitas tidak diartikan sebagai kehidupan tanpa konflik tetapi harmoni berarti keseimbangan diantara kepentingan maka tindakan strateginya adalah mengelola konflik, sedang prinsip harmoni yang dipahami sebagaimana kenyataan saat ini di Indonesia, pikiran ini akan menghasilkan tindakan yang cenderung untuk mengelola devide et impera.

Konflik dan kritik sosial tidak perlu dipahami sebagai tindakan yang akan membuat proses disintegrasi tetapi dapat memberi kontribusi terhadap harmonisasi sosial. Sebab stabilitas atau harmoni itu intinya adalah keseimbangan dari kehidupan konflik yang ada di dalam mana semua pihak saling mendapatkan imbalan yang sama. pada tingkat ini kritik sosial harus jelas dan transparan yang berfungsi sebagai sistem kontrol.

Pemikiran ini akan mengubah ketersinggungan, yang didasari tindakan atau emosional, menjadi lebih elegan yang berdasarkan atas penalaran bahwa kritik sangat diperlukan ketika ada orang lain dirugikan oleh sekelompok penguasa. Pada tingkat ini tidak ada lagi ketersinggungan misalnya apabila presiden Amerika Serikat menyatakan bahwa Indonesia termasuk negara yang tergolong tidak demokratis.

${ }^{15}$ Meskipun hingga kini ketua Partai Buruh belum mau bernegosiasi dengan pemerintah, presiden Kim Young Sam telah mengakui bahwa Undang-undang Perburuhan Korea yang baru telah mengandung beberapa kekeliruan. Lihat Bernas 22 Januari 1997. 
Demikian pula masyarakat hirakial lambat laun akan menjadi longgar dan pelaksanaan UU dapat dikontrol oleh kehidupan publik. Pada aras ini, orang akan meletakkan pikiran bahwa masyarakat itu pada dasarnya memang konflik, kemudian mengelolanya untuk mencapai keseimbangan dan pada saat itu prinsip harmoni atau stabilitas dapat ditegakkan dalam realitas. Pemikiran ini, dapat atau tidak, berlangsung di Indonesia tergantung kepada bangsa Indonesia sendiri untuk mewujudkan di tengah-tengah rangkaian sistem sosial budaya dengan paham harmoni sebagai kebutuhan kepentingan publik, bukan harmoni sebagai bentuk keinginan kepentingan individu atau kelompok.

\section{Penutup}

Sehubungan dengan lingkaran penafsiran sistemik yang terjadi dalam realitas empirik akibat dari paham harmoni yang selama ini diyakini oleh penguasa, ada dua hal yang hendak penulis sampaikan untuk menutup tulisan ini. Pertama, jika realitas empiris yang berkembang saat ini dianggap sebagai kemantapan stabilitas politik, sebab konflik semakin meningkat frekwensinya dapat dengan yakin diatasi melalui instrumen keamanan yang ada dengan jalan menekan atau memaksa, maka ketidak puasan dan tingkat kepercayaan rakyat terhadap penguasa semakin menurun. Jika keadaan ini terus berlangsung, perubahan lambat-laun akan terjadi dengan lahirnya konflik yang berujud kerusuhan yang semakin meluas dan kritik sosial semakin transparan. Siapa yang berperan sebagai "tangan-tangan setan" dibalik kerusuhan, kalau hal ini benar-benar ada akan sulit mengontrol proses integrasi bangsa. Apapun keadaannya rakyat akan menunggu datangnya "Ratu Adil" (millenarianisme). ${ }^{16}$ Lingkaran realitas empiris yang berlangsung secara sistemik akan berubah dengan sendirinya, namun perubahan macam apa yang akan terjadi masih sulit untuk diprediksi.

Kedua, perubahan dapat direncanakan dengan merubah cara memahami prinsip stabilitas. Perubahan cara memahami harmoni dengan memperhatikan dan mengelola konflik menuju keseimbangan dan bukan berusaha sekuat tenaga menghapuskan bentuk-bentuk konflik atau perbedaan. Pada tingkat pemikiran ini kemungkinan besar proses integrasi masih dapat dikontrol. Dalam konteks sistem budaya perubahan tingkat ide akan menentukan pembentukan pranata baru yang berhubungan dengan segala aspek kehidupan. Akhirnya pilihan mana yang akan diambil untuk keberlanjutan pembangunan bangsa Indonesia tergantung pada penguasa dan rakyat.

\section{Daftar Pustaka}

Abdullah, Taufik, Strategi Kebudayaan untuk Pemberdayaan Masyarakat; Sebuah Sketsa untuk Penjelajahan Metodo-logis, Media Inovasi, Jurnal UMY, No. 2 Tahun vii//1996.

Giddens, Anthony, Capitalism and Modern Sosial Theory.

Hudayana, Bambang, Memahami Identitas Kultural dalam Era Globalisasi, Sebuah Review karya Freidman Cultural Identity \& Global Process, Jurnal Kebangsaan Indonesia, Vol. 1, No. 1, 1997.

${ }^{16}$ Dalam situasi krisis dimana masyarakat tidak mengerti lagi apa yang akan dilakukan akibat dari tindakan kekuasaan, pilihan masyarakat terhadap datangnya ratu adil mempunyai potensi pemberontakan yang begitu besar, lihat Sartono Kartodirdjo, Ratu Adil, hal. 39. 
Topik: Harmoni Stabilitas Politik..., Susetiawan

Kartono Kartodihardjo, Sartono, Ratu Adil, Sinar Harapan, Jakarta, 1984.

Kieden Ignas, Sikap IImiah dan Kritik Kebudayaan, LP3ES, Jakarta, 1984.

Koentjoroningrat, Kebudayaan Mentalitet dan Pembangunan, Gramedia, Jakarta, 1994.

Basu, Sharma, Aspect of Industrial Relations in ASEAN, ISEAS, Singapura, 1985.
Susetiawan, Cultural Values, Organization and Performance of Industrial Workers in Indonesia, disertation belum diterbitkan.

Ulhaq, Mahbub, Tirai Kemiskinan.

Majalah Forum Keadilan, No. 21, tahun v, 27 Januari 1997. 